\title{
Responses of Apple Plants to Drought Stress
}

\author{
Servet Aras (Corresponding author) \\ Faculty of Agriculture, Department of Horticulture, Yozgat Bozok University \\ PO Box 66200, Yozgat, Turkey \\ E-mail: servet.aras@bozok.edu.tr \\ Hakan Keles \\ Faculty of Agriculture, Department of Horticulture, Yozgat Bozok University \\ PO Box 66200, Yozgat, Turkey \\ E-mail: hakan.keles@bozok.edu.tr
}

Received: July 11, 2019 Accepted: August 1, 2019 Published: August 14, 2019

doi:10.5296/jas.v7i3.15271

URL: https://doi.org/10.5296/jas.v7i3.15271

\begin{abstract}
In order to screen apple rootstocks for drought tolerance, two different drought levels moderate and severe stress, and a control were applied to apple cultivar Red Chief grafted onto M9 and MM106 rootstocks. Apple plants were subjected to drought stress by withholding water for 15 and 19 days in the greenhouse conditions, while the control treatment was continued watering. Data were recorded 15 (moderate drought stress) and 19 days (severe drought stress) after application of drought stress. At the end of the experiment, both rootstocks were significantly affected under drought conditions. Severe drought stress caused decrease in SPAD value in Red Chief grafted onto M9 and MM106 by $15.7 \%$ and $11.1 \%$, respectively. Severe drought stress declined anthocyanin content in M9 and MM106 by $7.8 \%$ and $28.4 \%$, respectively. Stomatal conductance was remarkably affected by drought stress. Effects of drought stress on plants depended on rootstocks, severity and duration of drought stress. As a result, the more invigorating rootstock MM106 was found more drought-tolerant when compared to M9 that is needed to be evaluated with more parameters.
\end{abstract}

Keywords: apple, drought stress, malus, response, rootstock

\section{Introduction}

Apple (Malus domestica Borkh) from the family Rosaceae, which includes one-third of all flowering plants, is the main fruit crop of temperate regions of Turkey and in the world. In Turkey, it is grown on an area of 175.357 hectares with annual production of 3.032.164 tons 
(FAOSTAT, 2017). However, the apple cultivation in several regions can be restricted due to drought stress since apple is a drought stress sensitive crop (Zhang et al., 2013). Drought stress is commonly the challenging factor in intensive apple growing areas due to high temperatures and water deficit in the summer. Furthermore, dwarfing rootstocks are used in intensive orchards that causes decrease in water uptake from soil due to its shallow roots under water deficit conditions. Nutrient utilization by plants decreases under water deficit conditions that results in decline in photosynthesis (Nemeskéri et al., 2009).

Apple cultivation under drought conditions causes several deleterious effects which includes increases in reactive oxygen species (ROS), reduction in nutrient uptake, and damages in cell membranes (Šircelj et al., 2007; Bhusal et al., 2019). ROS cause oxidative stress that damages chlorophyll membranes (Fita et al., 2015). Plants exhibit many physiological and biochemical responses in order to cope with the malignant effects of stresses and the responses are related with rootstock ability in grafted plants. To deal with drought damage, drought tolerant rootstocks can be used. Rootstocks improve tree size, fruit yield and quality. It's been demonstrated that rootstocks play a pivotal role in plant stress tolerance (Del Carmen Gijón et al., 2010; Aras and Eşitken, 2018; 2019b). In a previous study, we evaluated M9 and MM106 apple rootstocks under short term salinity stress. MM106 provided more salinity-tolerance on the cultivar "Fuji" compared to M9 (Aras and Eşitken, 2019a). Tworkoski et al. (2016) studied drought stress on M9 and MM111 apple rootstocks. They found MM111 highly drought tolerant and attributed its higher tolerance to more extensive root system. It has been found that vigor rootstocks show more drought tolerance by increasing assimilates to root development (Bauerle et al., 2011). Many studies have demonstrated that vigor rootstocks are capable to survive under drought conditions through deeper root systems. There is however, limited knowledge on survival on shallow soils under drought conditions. Understanding plant responses to drought stress under shallow soils is very critical.

The objective of this experiment was to study the influences of two different clonal rootstocks (M9 and MM106) against drought stress in apple plant (Malus domestica Borkh) cv. Red Chief under potted condition.

\section{Materials and Methods}

This study was conducted in pots, in a semi-controlled greenhouse at Yozgat Bozok University. One-year-old, clonally propagated apple cv. Red Chief (Malus domestica Borkh) grafted onto M9 and MM106 rootstocks were planted in $10 \mathrm{~L}$ plastic pots containing perlite in March in 2019. The experimental design was randomized complete block in three replications. Each plot had three plants per replicate. The plants were placed in a semi-controlled greenhouse where PAR was 35.000-40.000 lux and temperature fluctuated between $25-35^{\circ} \mathrm{C}$ in the day. Plants were well irrigated and drained until the initiation of the drought experiment. The plants were watered regularly and fertilized once a week with Hoagland's nutrient solution (Hoagland and Arnon, 1950). Apple plants were subjected to drought stress by withholding water for 15 days and 19 days in the greenhouse conditions, while the control treatment was continued watering. 
Relative chlorophyll (SPAD) value was measured with a Minolta SPAD-502 chlorophyll meter (Minolta Camera Co, Ltd, Osaka, Japan). The ACM-200 plus Anthocyanin Content Meter was used to measure relative anthocyanin content. Stomatal conductivity and leaf temperature were measured on the youngest fully expanded leaves on upper branches of the plants with leaf porometer (Li-COR).

Leaf relative water content (LRWC) was determined by the procedure of Smart and Bingham (1974). Leaves were collected from the young fully expanded leaves of three plants per replicate. Individual leaves first detached from the stem and then weighted to determine fresh weight (FW). In order to determine turgid weight (TW), leaves were floated in distilled water inside a closed petri dish. Leaf samples were weighted periodically, after gently wiping the water from the leaf surface with the tissue paper until a steady state was achieved. At the end of imbibition period, leaf samples were placed in a pre-heated oven at $72^{\circ} \mathrm{C}$ for $48 \mathrm{~h}$, in order to determine dry weight (DW). Values of FW, TW, and DW were used to calculate LRWC using the equation given below:

$$
\operatorname{LRWC}(\%)=[(\mathrm{FW}-\mathrm{DW}) /(\mathrm{TW}-\mathrm{DW})] \times 100
$$

The statistical analyses were performed with the statistical software package SPSS, version 20.0. Data were subjected to two-way ANOVA and were seperated by the Duncan's test at a significance level of $\mathrm{P}<0.05$.

\section{Results}

Some responses related with plant physiology were measured to define the effect of drought conditions on apple plants following 15 days and 19 days of drought stress treatment. Both rootstocks were significantly affected under drought conditions. Severe drought stress caused decrease in SPAD value in Red Chief grafted onto both rootstocks. The lowest SPAD value was in M9 (47.36). Moderate stress decreased the value by 13.6 and $3.5 \%$, respectively. The differences in both treatments and rootstocks were significant for anthocyanin content. Severe and moderate drought stress remarkably declined anthocyanin content in M9 and MM106 (Table 1).

Table 1. Effect of drought stress SPAD and anthocyanin content

\begin{tabular}{|c|c|c|c|c|c|c|}
\hline \multirow[b]{2}{*}{ Treatments } & \multicolumn{3}{|l|}{ SPAD } & \multicolumn{3}{|c|}{ Anthocyanin } \\
\hline & M9 & $\begin{array}{l}\text { MM10 } \\
6\end{array}$ & $\begin{array}{l}\text { Mean } \\
\text { s }\end{array}$ & M9 & $\begin{array}{l}\text { MM10 } \\
6\end{array}$ & Means \\
\hline Control & $56.20^{\mathrm{a}}$ & $59.30^{\mathrm{a}}$ & 57.75 & 9.60 & $11.20^{\mathrm{b}}$ & $10.40^{\mathrm{B}}$ \\
\hline Moderate Drought & $48.56^{\mathrm{ab}}$ & $57.20^{\mathrm{ab}}$ & 52.88 & 10.13 & $11.31^{\mathrm{b}}$ & $10.72^{\mathbf{B}}$ \\
\hline Severe Drought & $47.36^{b}$ & $52.96^{\mathrm{b}}$ & 50.16 & 10.35 & $14.38^{\mathrm{a}}$ & $12.36^{\mathbf{A}}$ \\
\hline Means & 50.71 & 56.48 & & $10.02^{\mathrm{A}}$ & $12.30^{\mathbf{B}}$ & \\
\hline $\begin{array}{l}\text { Rootstocks } \\
\text { Treatments }\end{array}$ & NS & & & $*$ & & \\
\hline
\end{tabular}


Means separation within the columns and line by Duncan's multiple range test $(\mathrm{P}<0.05)$. NS-not significant, $*$ - $\mathrm{p} \leq 0.05$

Leaf relative water content decreased by drought conditions (Table 2). Under severe drought stress condition, LRWC values were found in M9 and MM106 as $64.63 \%$ and $66.89 \%$, respectively. Moderate stress decreased the value by 4.22 and $15.9 \%$, respectively. Stomatal conductance was remarkably affected by drought stress. Under severe drought condition, stomatal conductance decreased in Red Chief grafted onto MM106 by $88.26 \%$, while it decreased in Red Chief grafted onto M9 by $82.9 \%$. Leaf temperature was not significantly affected for both rootstocks (Table 2).

Table 2. Effect of drought stress on LRWC, stomatal conductivity and leaf temperature

\begin{tabular}{|c|c|c|c|c|c|c|c|c|c|}
\hline \multirow[t]{2}{*}{ Treatments } & \multicolumn{3}{|c|}{ LRWC (\%) } & \multicolumn{3}{|c|}{$\begin{array}{l}\text { Stomatal Conductivity } \\
\left(\mathrm{mmol} \mathrm{m}^{-2} \mathrm{~s}^{-1}\right)\end{array}$} & \multicolumn{3}{|c|}{ Leaf Temperature $\left({ }^{\circ} \mathrm{C}\right)$} \\
\hline & M9 & MM106 & Means & M9 & MM106 & Means & M9 & MM106 & Means \\
\hline Control & $\begin{array}{l}84.18 \\
\text { a }\end{array}$ & $82.86^{\mathrm{a}}$ & 83.52 & $\begin{array}{l}180.20 \\
\mathrm{a}\end{array}$ & $\begin{array}{l}205.33 \\
\mathrm{a}\end{array}$ & 192.76 & $34.46^{\mathrm{NS}}$ & $34.76^{\mathrm{NS}}$ & 34.61 \\
\hline $\begin{array}{l}\text { Moderate } \\
\text { Drought }\end{array}$ & $\begin{array}{l}80.62 \\
a\end{array}$ & $69.67^{\mathrm{ab}}$ & 75.14 & $\begin{array}{l}50.43 \\
b\end{array}$ & $43.00^{\mathrm{b}}$ & 46.71 & 34.33 & 34.63 & 34.48 \\
\hline $\begin{array}{l}\text { Severe } \\
\text { Drought }\end{array}$ & $\begin{array}{l}64.63 \\
b\end{array}$ & $66.89^{b}$ & 65.76 & $\begin{array}{l}30.80 \\
\text { b }\end{array}$ & $24.10^{\mathrm{b}}$ & 24.45 & 34.73 & 34.76 & 34.75 \\
\hline Means & 76.48 & 73.14 & & 87.14 & 90.81 & & 34.51 & 34.72 & \\
\hline $\begin{array}{l}\text { Rootstocks } \\
\mathrm{x} \\
\text { Treatments }\end{array}$ & NS & & & NS & & & NS & & \\
\hline
\end{tabular}

Means separation within the columns and line by Duncan's multiple range test $(\mathrm{P}<0.05)$. NS-not significant, $*_{\text {- }} \mathrm{p} \leq 0.05$

\section{Discussion}

M9 and MM106 have been the leading rootstocks in Turkey apple production. It is known that MM106 is more vigorous than M9 and the roots of MM106 are deeper helping scions to survive under drought conditions by growing deeper in the soil.

SPAD value represents a parameter to evaluate the chlorophyll content. Change in the chlorophyll content is demonstrated as an indicator of plant status under stress conditions and many studies have reported that drought stress decreases the chlorophyll content in leaves (Hamann et al., 2018; Bhusal et al., 2019). In our study, loss in chlorophyll was less in Red Chief on MM106 for both moderate and severe drought stresses compared to the control.

Several studies have showed that anthocyanins are capable to scavenge reactive oxygen species (Efeoğlu et al., 2009; Sperdouli and Moustakas, 2012). Drought stress caused a strong increase in anthocyanin content. In severe drought, anthocyanin content of Red Chief 
on MM106 increased by 28,4\% that shows MM106 utilizes anthocyanins as a defense mechanism under severe drought condition. Under moderate drought condition, M9 triggered more anthocyanin accumulation than MM106.

Leaf relative water content is another indicator of drought stress reflecting plant cellular osmotic adjustment under cellular dehydration (Hamann et al., 2018). Decrease in leaf water status prevents chlorophyll functioning (Guerfel et al., 2009; Bhusal et al., 2019). Thus, greater reduction in chlorophyll in M9 may be due to the severe reduction in LRWC under severe drought stress condition. Reduction in LRWC as a result of drought stress was reported in apple (Liu et al., 2012), almond (Alimohammadi et al., 2013), and sweet cherry (Javadi et al., 2017).

Decline in stomatal conductance is a defense mechanism to avoid water loss from leaf surface (Mahouachi, 2009). Some experiments have found that more vigorous rootstocks have greater stomatal conductance than dwarfing rootstocks (Atkinson et al., 2000; Tworkoski et al., 2016). In the present study, MM106, more vigorous rootstock, showed higher stomatal conductance compared to M9 and also more decreased in stomatal conductance under drought conditions. Fernandez et al. (1997) stated that abscisic acid (ABA), a responsible phtytohormone for stomatal closure, was higher M9 than more vigorous rootstocks that leads to decline in stomatal conductance. Under drought conditions, MM106 showed greater changes in stomata compared to M9 that may be attributed to possessing higher ABA under stress condition.

\section{Conclusion}

Effects of drought stress on apple plants depend on rootstocks, severity and duration of drought stress. Based on the current study stomatal conductance is a suitable marker for drought stress. When control plants of M9 and MM106 are compared, it is observed that LRWC is greater in M9 that may be a result of drawing more water from roots to leaves and more stomatal closure for water conservation.

\section{References}

Alimohammadi, A., Shiran, B., Martínez-Gómez, P., \& Ebrahimie, E. (2013). Identification of water-deficit resistance genes in wild almond Prunus scoparia using cDNA-AFLP. Scientia Horticulturae, 159, 19-28. https://doi.org/10.1016/j.scienta.2013.04.023

Aras, S., \& Eşitken, A. (2018). Physiological responses of cherry rootstocks to short term salinity. Erwerbs-Obstbau, 60, 161-164. https://doi.org/10.1007/s10341-017-0350-x

Aras, S., \& Eşitken, A. (2019a). Responses of Apple Plants to Salinity Stress. Yüzüncü Yıl University Journal of Agricultural Science, 29(2), 253-257.

https://doi.org/10.29133/yyutbd.494677

Aras, S., \& Eşitken, A. (2019b). Responses of Cherry Plant Grafted onto CAB-6P, MaxMa 14 and Mazzard Rootstocks to Short Term Salinity. Journal of Agricultural Studies, Accepted. https://doi.org/10.5296/jas.v7i3.15114 
Atkinson, C. J., Policarpo, M., Webster, A. D., \& Kingswell, G. (2000). Drought tolerance of clonal Malus determined from measurements of stomatal conductance and leaf water potential. Tree Physiology, 20, 557-563. https://doi.org/10.1093/treephys/20.8.557

Bauerle, T. L., Centinari, M., \& Bauerle, W. L. (2011). Shifts in xylem vessel diameter andembolisms in grafted apple trees of differing rootstock growth potential inresponse to drought. Planta, 234, 1045-1054. https://doi.org/10.1007/s00425-011-1460-6

Bhusal, N., Han, S. G., \& Yoon, T. M. (2019). Impact of drought stress on photosynthetic response, leaf water potential, and stem sap flow in two cultivars of bi-leader apple trees (Malus $\times$ domestica Borkh.). Scientia Horticulturae, 246, 535-543.

https://doi.org/10.1016/j.scienta.2018.11.021

del Carmen Gijón, M., Gimenez, C., Perez-López, D., Guerrero, J., Couceiro, J. F., \& Moriana, A. (2010). Rootstock influences the response of pistachio (Pistacia vera L. cv. Kerman) to water stress and rehydration. Scientia horticulturae, 125(4), 666-671.https://doi.org/10.1016/j.scienta.2010.05.026

Efeoğlu, B., Ekmekci, Y., \& Cicek, N. (2009). Physiological responses of three maize cultivars to drought stress and recovery. South African Journal of Botany, 75(1), 34-42. https://doi.org/10.1016/j.sajb.2008.06.005 FAOSTAT. 2017.

Fernandez, T. R., Perry, R. L., \& Flore, J. A. (1997). Drought response of young apple treeson three rootstocks. II. Gas exchange, chlorophyll fluorescence, water relations, and leaf abscisic acid. Journal of the American Society for Horticultural Science, 122, 841-848. https://doi.org/10.21273/JASHS.122.6.841

Fita, A., Rodríguez-Burruezo, A., Boscaiu, M., Prohens, J., \& Vicente, O. (2015). Breeding and domesticating crops adapted to drought and salinity: a new paradigm for increasing food production. Frontiers in Plant Science, 6, 978. https://doi.org/10.3389/fpls.2015.00978

Guerfel, M., Baccouri, O., Boujnah, D., Chaïbi, W., \& Zarrouk, M. (2009). Impact of water stress on gas exchange, water relations, chlorophyll content and leaf structure in two main Tunisian olive (Olea europaea L.) cultivars. Scientia Horticulturae, 119, 257-263. https://doi.org/10.1016/j.scienta.2008.08.006

Hamann, F. A., Czaja, S., Hunsche, M., Noga, G., \& Fiebig, A. (2018). Monitoring physiological and biochemical responses of two apple cultivars to water supply regimes with non-destructive fluorescence sensors. Scientia Horticulturae, 242, 51-61.

https://doi.org/10.1016/j.scienta.2018.07.008

Hoagland, D. R., \& Arnon, D. I. (1950). The water-culture method for growing plants without soil. Circular, 347. Agricultural Experiment Station, University of California, Berkeley.

Javadi, T., Rohollahi, D., Ghaderi, N., \& Nazari, F. (2017). Mitigating the adverse effects of drought stress on the morpho-physiological traits and anti-oxidative enzyme activities of Prunus avium through $\beta$-amino butyric acid drenching. Scientia Horticulturae, 218, 156-163. https://doi.org/10.1016/j.scienta.2017.02.019 


\section{Macrothink}

Liu, B., Li, M., Cheng, L., Liang, D., Zou, Y., \& Ma, F. (2012). Influence of rootstock on antioxidant system in leaves and roots of young apple trees in response to drought stress. Plant Growth Regulation, 67(3), 247-256. https://doi.org/10.1007/s10725-012-9683-5

Mahouachi, J. (2009). Changes in nutrient concentrations and leaf gas exchange parameters in banana plantlets under gradual soil moisture depletion. Scientia Horticulturae, 120, 460-466. https://doi.org/10.1016/j.scienta.2008.12.002

Nemeskéri, E., Sárdi, É., Kovács-Nagy, E., Stefanovits-Bányai, É., Nagy, J., Nyéki, J., \& Szabó, T. (2009). Studies on the drought responses of apple trees (Malus domestica Borkh.) grafted on different rootstocks. International Journal of Horticultural Science, 15(1-2), 29-36. https://doi.org/10.31421/IJHS/15/1-2/809

Šircelj, H., Tausz, M., Grill, D., \& Batič, F. (2007). Detecting different levels of drought stress in apple trees (Malus domestica Borkh.) with selected biochemical and physiological parameters. Scientia Horticulturae, 113(4), 362-369.

https://doi.org/10.1016/j.scienta.2007.04.012

Smart, R. E., \& Bingham, G. E. (1974). Rapidest mates of relative water content. Plant Physiology, 53, 258-260. https://doi.org/10.1104/pp.53.2.258

Sperdouli, I., \& Moustakas, M. (2012). Interaction of proline, sugars, and anthocyanins during photosynthetic acclimation of Arabidopsis thaliana to drought stress. Journal of Plant Physiology, 169(6), 577-585. https://doi.org/10.1016/j.jplph.2011.12.015

Tworkoski, T., Fazio, G., \& Glenn, D. M. (2016). Apple rootstock resistance to drought. Scientia Horticulturae, 204, 70-78. https://doi.org/10.1016/j.scienta.2016.01.047

Zhang, L., Gao, M., Zhang, L., Li, B., Han, M., Alva, A. K., \& Ashraf, M. (2013). Role of exogenous glycinebetaine and humic acid in mitigating drought stress-induced adverse effects in Malus robusta seedlings. Turkish Journal of Botany, 37(5), 920-929. https://doi.org/10.3906/bot-1212-21

\section{Copyright Disclaimer}

Copyright for this article is retained by the author(s), with first publication rights granted to the journal.

This is an open-access article distributed under the terms and conditions of the Creative Commons Attribution license (http://creativecommons.org/licenses/by/4.0/). 